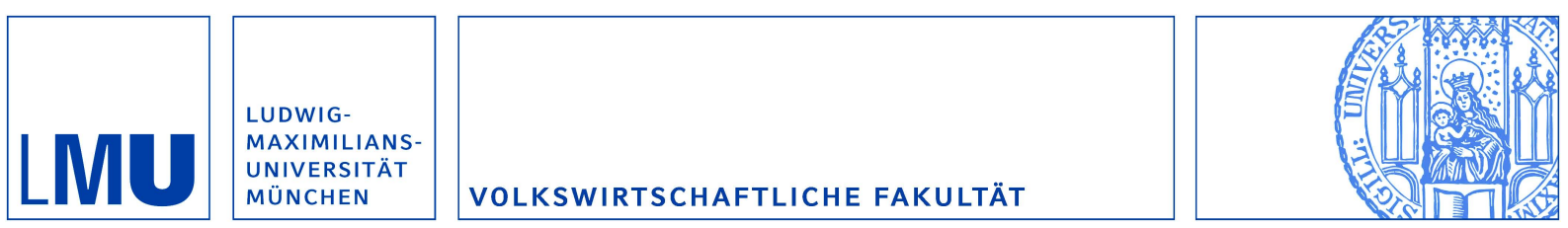

Eicher, Theo und Leukert, Andreas:

Institutions and Economic Performance: Endogeneity and Parameter Heterogeneity

Munich Discussion Paper No. 2006-5

Department of Economics

University of Munich

Volkswirtschaftliche Fakultät

Ludwig-Maximilians-Universitäł München

Online at https://doi.org/10.5282/ubm/epub.775 


\title{
Institutions and Economic Performance: Endogeneity and Parameter Heterogeneity
}

\author{
Theo Eicher* \\ University of Washington \\ Ifo Institute of Economic Research \\ Andreas Leukert \\ Ludwig-Maximilians-Universität München
}

Draft 3.5

September 292005

\begin{abstract}
The hallmark of the recent development and growth literature is a quest to identify institutions that explain a significant portion of the observed differences in living standards across countries. Empirical work in the area focuses almost exclusively on either the global sample or on developing nations. Certainly it is important to know which institutions are lacking in these developing countries, but the analysis provides little evidence for us to know to what extend a common set of institutions actually matters in advanced and developing countries. In this paper we examine parameter heterogeneity in prominent approaches to institutions and economic performance. We find that a new set of instruments is necessary to control for endogeneity, but that a common set of economically important institutions does indeed exist among advanced and developing nations. The impact of these institutions does vary substantially across samples; it is about three times as high in developing countries as compared to OECD countries.
\end{abstract}

Key words: Economic Institutions, Political Institutions, OECD and Developing Countries Economic Performance, Parameter Heterogeneity

JEL Classification: $\mathrm{O} 1, \mathrm{O} 4, \mathrm{P} 0$

We thank Chris Papageorgiou for helpful discussions and Torsten Persson for making his dataset available to us. *Box 353330, University of Washington, Seattle WA 98105 USA, te@u.washington.edu. andreas.leukert@lrz.uni-muenchen.de 


\section{Introduction}

The hallmark of the recent development and growth literature is a quest to identify institutions that explain a significant portion of the observed differences in living standards across countries. ${ }^{1}$ While the definitions of "institutions" may vary across studies, the results are consistent and strong: institutions explain economically and statistically significant differences in per capita incomes across countries. ${ }^{2}$ The set of countries under observation is at times dictated by data availability, but generally the literature examines either the global sample or developing countries. The types of institutions that have been associated with economic performance commonly relate to measures of government risk of expropriation, rule of law, bureaucratic quality, corruption, government repudiation of contracts, civil liberties, and openness to trade.

Rather surprising is, however, the absence of a comprehensive literature that analyzes which institutions determine the economic fortunes in developed nations. One might expect, for example, that the above cited institutions hardly vary across OECD countries - too little, perhaps, to provide insights into how these nations achieve and maintain their rank at the front of the income frontier. In this paper, we examine parameter heterogeneity as it relates to the influence of institutions on output in OECD and Non-OECD subsamples. We seek to examine whether a set of institutions exists which contains explanatory power and economic influence in both subsamples.

While the literature provides ample guidance as to which institutions are commonly lacking in developing countries, there exists only a rudimentary understanding to what degree the same institutions actually matter in OECD countries. Research that focuses on advanced economies excludes the rest of the world; as a result, such studies focus on completely different

\footnotetext{
${ }^{1}$ Depending on the dataset, income per worker differences are 35- or 94-fold (Hall and Jones, 1999 or Caselli, 2005).
} 
sets of institutions, such as labor market institutions (e.g., Nickell, Nunziata, and Ochel, 2005, and Boeri, Nicoletti, and Scarpetta, 2000), traditional factor markets such as human and physical capital (e.g., Bassanini, Hemmings, and Scarpetta, 2001), product regulations (e.g., Nicoletti and Scarpetta, 2003), conflict resolution procedures (De Grauwe and Skudenly, 1999 and Schneider and Wagner, 2001) or financial markets regulation (Carlina and Mayerb, 2001). It is undeniably true that these institutions are crucial determinants of economic performance in advanced countries. Our focus is different; we seek to establish the impact of those institutions that have been shown to hold strong explanatory power in global regressions and to examine whether they also hold explanatory power in the OECD subsample. The goal is to establish a set of institutions that matter not only in advanced or developing countries, but are fundamental determinants of economic performance in both.

Since we seek to investigate whether a set of institutions exists that matters across all countries, our point of departure is the Hall and Jones (1999) methodology which includes instruments to control for the potential endogeneity of institutions in a global, structural model. While their institutional quality measure is clearly correlated with income per worker in the global sample (see Figure 1), the simple OLS regression lines for the two subsamples indicate a differential impact in OECD countries as compared to the rest of the sample. OECD countries do seem to have a noticeably lower slope than Non-OECD countries. However, conclusive statements to that effect require solid analysis and extensive testing of robustness and endogeneity.

To address issues of parameter heterogeneity we employ two approaches. First, we split the sample and second, we use the interaction methodology of Brock and Durlauf (2001), who

\footnotetext{
2 For prominent examples of definitions of "institutions," "economic institutions," "social infrastructure," or "structural policies" see Rodrik, Subramanian, and Trebbi (2004), Acemoglu, Johnson, and Robinson (2001), Hall and Jones (1999) or Persson (2004), respectively.
} 
applied this approach after calling into question whether institutional indices can reasonably be expected to exhibit parameter homogeneity across "complex heterogeneous objects such as countries." Specifically, they cite the case of the United States and Russia, where Civil Liberties data can hardly be seen to have a similar impact on economic performance.

Our results are not limited to a simple assessment of the impact of established institutions on output in global and OECD samples. As we examine parameter heterogeneity, we find that the established instruments are invalid when we split the sample into OECD and Non-OECD countries. This forces us to consider a new set of appropriate instruments in order to successfully control for endogeneity in all subsamples before we can examine the economic impact of institutions on output.

Our new set of instruments is based on the hierarchy of institutions hypothesis. The hypothesis is laid out in detail in Acemoglu, Johnson, and Robinson (2005) and similar approaches have provided empirical validation for such a hierarchy (see Persson, 2004, 2005 and Eicher and Schreiber, 2005). The basic argument is that the constitutional institutions/political rules set the stage for the economic institutions. We thus divide institutions into two dimensions: constitutional/political institutions to serve as instruments, and economic institutions that are thought to exert direct effects on output.

Extensive robustness analysis confirms that the set of established economic institutions is indeed highly significant and holds great explanatory power in both OECD and Non-OECD countries. However, evidence for parameter heterogeneity is strong. We show that these economic institutions matter significantly more in Non-OECD countries than in the global sample, and about two thirds less in OECD than in Non-OECD countries. This highlights that the estimates obtained in the previous literature for the global sample are a weighted average of the impact of institutions on economic performance in advanced and developing countries. 
The new set of political instruments that we propose performs strongly across subsamples, and our results are shown to be robust to a number of alternative specifications and tests. The coefficient estimates for the political instruments are highly significant in all subsamples indicating the important impact of such institutions on the fabric of economic institutions in both advanced and developing nations.

The paper is organized as follows: Section 2 first motivates the investigation into parameter heterogeneity for both instruments and economic institutions. Here we utilize the Hall and Jones (1999) framework and examine two main subsamples: OECD-members and nonmembers and show how the established instruments fail in section 2.1. Section 2.2 introduces alternative instruments based on the hierarchy of institutions hypothesis. Section 3 consists of a series of robustness checks which examine different time periods, datasets and samples, before Section 4 concludes.

\section{Parameter Heterogeneity in Instruments and Institutions}

\subsection{Established Instruments and Institutions}

We approach parameter heterogeneity sequentially, first examining the possibility of heterogeneity in the instruments, and subsequently focusing on economic institutions. This progression is necessary because we must establish valid instruments across samples (Global, OECD, and Non-OECD). In the absence of valid instruments, the investigation of the impact of economic institutions on output is tarnished by endogeneity bias. Parameter heterogeneity would bias the global regressions even further.

Among the established instruments for economic institutions, immediate candidates for parameter heterogeneity relate to the notion of Western European historical influence. Hall and Jones (1999) and Engerman and Sokoloff (1997) provide extensive motivation and historical analysis, respectively, to support the use of those instruments that relate to specific European 
development influences (e.g., Europeans either settled the countries or the countries speak a European language). ${ }^{3}$ The idea is that the colonizers and immigrants brought along with them the basic prerequisites to establish those economic institutions that are conducive to economic development.

For OECD countries the instruments relating to European languages can only be justified if they exhibit sufficient exogenous identifying variation and if they retain similar explanatory power as in the global sample. In addition, the validity of these instruments is directly related to how well they can be motivated. Since most OECD countries were the source of the influence that the instruments are supposed to measure, the motivation is called into question. Specifically, measuring the positive influence of a country's own historical experience upon itself makes for weak instruments.

A similar line of reasoning raises questions about Latitude (distance from the equator) as an appropriate instrument for OECD countries. Certainly, the preference of European settlers to emigrate to similar Latitudes can be seen as a strong motivation for Latitude's influence on economic institutions in developing nations. However, one might argue that, by definition, Latitude holds little power in OECD countries - most of whom were the very source of the settlers.

The last instrument Hall and Jones (1999) employ is the Frankel and Romer (1996, 1999) Implied Trade Share for a country. This measure provides geography-based explanations for trade derived from a gravity approach. Deviations from the implied trade share could thus signal weak, protectionist institutions. While this instrument may appear most suitable for different sub-

\footnotetext{
${ }^{3}$ Hall and Jones (1999) refer to English, French, German, Portuguese, and Spanish languages and Western Europe's discovery of "the ideas of Adam Smith, the importance of property rights, and the system of checks and balances in government."
} 
groups of countries, protectionism has been uniformly low in OECD countries which leads us to suspect that the variable will hold little explanatory power for subsamples of countries.

We commence with simple diagnostics to ascertain the validity of instruments and economic institutions across OECD and Non-OECD subsamples. Subsequently, we address the core issue at hand: are the relevant economic institutions in OECD countries similar to those in the rest of the world? This question has two dimensions. First, we may ask if there exists a common set of economic institutions that determines income in OECD and Non-OECD countries. Certainly, rule of law, bureaucratic quality, corruption, risk of expropriation, government repudiation of contracts, and openness to trade (the components of Hall and Jones ${ }^{6}$ (1999) "social infrastructure" index) are key traits for development. However, in developed nations, by definition, one might be skeptical whether these types of economic institutions are indeed the relevant ones. If a common set of economic institutions exists, the second dimension examines whether their influence on output is uniform across OECD and Non-OECD countries.

To establish a benchmark, we follow the methodology introduced by Hall and Jones (1999), who explore the effects of institutions on output by examining the structural model

$$
\log Y / L=\alpha+\beta I+\varepsilon
$$

where $Y / L$ denotes income per worker and $I$ is the measure of economic institutional quality. Recognizing that economic institutions are potentially endogenous to income, apart from being determined by a vector of exogenous factors, $X$, a regression identifying institutions is specified as

$$
I=\gamma+\delta \log Y / L+X \theta+\eta
$$

Due to the possible endogeneity of economic institutions, the OLS estimation of equation (1) establishes neither causality nor unbiased coefficients. Hall and Jones (1999) therefore provide instruments designed to solve the endogeneity problem. Candidates for instruments are selected 
from the vector of exogenous covariates, $X$, in equation (2). We adopt their instrumental variable estimation strategy to achieve identification and unbiased estimates. ${ }^{4}$

Valid instruments fulfill two criteria: they are $i)$ uncorrelated with the error term in equation (1), and ii) strongly correlated with the endogenous regressor, I. The two-stage least squares (2SLS) estimation can then be specified as

$$
\begin{aligned}
& I^{\bullet}=\tilde{\gamma}+\bar{X} \tilde{\theta}+\tilde{\eta} \\
& \log Y / L=\tilde{\alpha}+\beta I^{\bullet}+\tilde{\varepsilon},
\end{aligned}
$$

where $\bar{X}$ is a subset of $X$ and equations (3) and (4) represent the first and second stage regressions, respectively.

The 2SLS regression (I) in Table 1 replicates the Hall and Jones (1999) results for the global sample, where instruments are successful, in the sense that most regressors in the first stage are highly significant, the adjusted R-squared is satisfactorily high, and in that the overidentifying restrictions cannot be rejected.

[Table 1 here]

Hall and Jones' (1999) compelling motivation of Latitude, Implied Trade Shares, and the fraction of the population which speaks European languages as instruments is reflected in these instruments' strong performance in the global sample. Not only is the first stage strong, but instrumented institutions are highly significant and explain large differences in per capita income across countries.

As a first exploration of parameter heterogeneity to uncover possible differing effects of instruments and institutions in the OECD subsample, we add a region dummy, $D$, to the 2SLS regression (I). This modifies the structural model to:

\footnotetext{
${ }^{4}$ As pointed out by Hall and Jones (1999), a valid IV strategy can also address measurement error and omitted variable bias of OLS estimates.
} 


$$
\begin{aligned}
& I^{\bullet}=\tilde{\gamma}+\bar{X} \tilde{\theta}+\xi D+\tilde{\eta} \\
& \log Y / L=\tilde{\alpha}+\beta I^{\bullet}+\zeta D+\tilde{\varepsilon}
\end{aligned}
$$

The 2SLS regression (II) in Table 1 reports that the OECD dummy is indeed highly significant in the first stage. In addition, the introduction of a regional dummy changes the explanatory power of instrumented institutions significantly. Having accounted for OECD specific effects, only two of the original four Hall and Jones instruments remain significant. The Implied Trade Share actually gains significance, moving from 10 to 1 percent levels, while the significance of European Languages and Latitude is greatly reduced. The explanatory power of Latitude changes dramatically. It looses its 1 percent significance from the 2SLS regression (I) and shows no statistically significant impact on economic institutions in the 2SLS regression (II). Perhaps some of the explanatory power of the instruments in the global sample was derived from the fact that the instruments differed systematically across subsamples.

The fit of the first stage rises strongly as the adjusted R-squared improves, indicating an increase in the power of the instruments from the 2SLS regression (I) to the 2SLS regression (II). The introduction of the region dummy thus improves the fit of the first stage significantly, while the established instruments loose power. This provides additional evidence that the region dummy actually drives the results in the 2SLS regression (II). In addition, the Sargan Over-ID Test is now rejected, which raises further doubts about the validity of this particular set of instrumental variables.

The second stage holds two additional surprises. First, the OECD dummy is not significant, which indicates the absence of OECD specific effects in the determination of income levels. Second, the measure of institutions remains highly significant with hardly a change in the point estimate, as compared to Hall and Jones' (1999) original specification. The same is true for the fit of the second stage which is just marginally below the fit of the Hall and Jones (1999) 
regression. ${ }^{5}$ We must consider the second stage preliminary, however, since the estimates in equation (6) are potentially contaminated with endogeneity bias, given the weak performance of the first stage of the 2SLS regression (II). With this caveat in mind, we do note that the regression indicates that economic institutions are indeed important in accessing output in the global sample. The rule of law, bureaucratic quality, corruption, risk of expropriation, government repudiation of contracts, and openness to trade do seem to matter just as much for OECD countries as for the world.

Since the OECD dummy lacks explanatory power while economic institutions are highly significant, it is tempting to conclude that there exists little evidence for parameter heterogeneity in economic institutions. However, the estimation of their effect on income levels is only valid to the degree that the instruments can be established as appropriate. The first stage of the 2SLS regression (II) highlights that the instruments lack not only a compelling intuitive motivation for OECD countries, but also explanatory power. Perhaps most importantly, the instruments are neither uncorrelated with the error term in equation (1) (the Sargan Test is not accepted), nor are the four established instruments strongly correlated with the endogenous regressor, $I$. The first stage of regression (II) thus casts substantial doubt on the validity of the results obtained in the second stage regression; in addition, the presence of a highly significant OECD dummy in the first stage provides strong evidence of parameter heterogeneity in the instruments.

To explore the issue of instrument heterogeneity head on, we proceed to split the sample and examine OECD and Non-OECD subsamples separately in Table 2. The purpose is to isolate the impact of the established instruments and the explanatory power of economic institutions across the respective subsamples.

\footnotetext{
${ }^{5}$ We choose to report the second stage R-squared as an indicator of the fit, although it does not possess statistical meaning in the context of $2 \mathrm{SLS} / \mathrm{IV}$, since it measures the proportion of variation in the dependent variable that is accounted for by the fitted explanatory variables.
} 


\section{[Table 2 here]}

The 2SLS regression (III) provides further reason to doubt that the established instruments are appropriate for the case of the OECD sample. Of all four instruments, only Latitude remains weakly significant at the $10 \%$ level in the first stage. This is especially surprising since Latitude had lost explanatory power when we introduced the OECD dummy to the global sample in the 2SLS regression (II). The adjusted R-square drops sharply in the first stage, and the Over-ID Test is also rejected. All this points to further problems related to either weak or inappropriate instruments for the subsamples.

The coefficient on economic institutions remains highly significant in the 2SLS regression (III), but its magnitude is reduced to about one third of the size obtained in the global sample. The fit for the second stage regression also improves sharply. After considering the caveat that the economic institutions estimate may be contaminated by endogeneity bias, the second stage indicates that institutions do exert a positive effect on output in OECD countries, albeit a substantially smaller one.

We expected that the Non-OECD sample in the 2SLS regression (IV) would retain similar explanatory power as in the original Hall and Jones results in the 2SLS regression (I). The instruments were well motivated for the developing world, and the sample now excludes OECD countries for which the instruments have been shown to lack statistical power as well as economic intuition. From this point of view, one could even hope to see that the explanatory power of the institutions for the subset of developing countries should be enhanced. However, the results in the 2SLS regression (IV) are disappointing. Surprisingly, all instruments except the Implied Trade Share loose significance. The fit of the first stage approaches white noise indicating to our surprise that the instruments perform even worse than in the OECD sample. As in the case of OECD countries, the Over-ID Test is rejected in the 2SLS regression (IV). While 
the coefficient on economic institutions in the second stage remains highly significant, the adjusted R-squared is practically reduced to zero. Note that the coefficient on institutions in the Non-OECD sample rises slightly compared to the coefficient in the global sample (2SLS regression I). Given the weak performance of the first stage, however, we cannot view the second stage results as reliable.

In exploring whether the established instruments are valid for OECD countries, we therefore, quite inadvertently, uncover their weakness in both subsamples. Surprising is that the convincingly motivated instruments for the Non-OECD subsample are also ultimately rejected on the basis of the lack of both, significance and identification. One might suspect that the result is an artifact of having picked an unfortunate division of the global dataset. Therefore, we conducted the same exercise with qualitatively similar sample splits according to the World Bank classification of High/Medium/Low Income Countries. The results in (Va), (Vb), (VIa) and (VIb) are almost identical as in regressions (III) and (IV). The results in regressions (III) and (IV) are robust to different splits of the global data as the instruments lack significance and fail the Over-ID Test in all alternative subsamples reported in Table $2{ }^{6}$

Perhaps the findings in Table 2 provide a deeper understanding of why the Hall and Jones' (1999) instruments do not perform strongly in the Acemoglu, Johnson, and Robinson (2001) sample, which is dominated by former colonies. They show that colonial origins (proxied by settler mortality) as an instrument for economic institutions (in their case government expropriation risk) improves the 2SLS estimation compared to Hall and Jones' (1999) instruments. Since Acemoglu, Johnson, and Robinson (2001) focus only on former colonies, their approach cannot be utilized to solve the endogeneity problem in OECD sample, which is comprised largely of the nations of origin of the settlers. 
The analysis leaves the discussion regarding the impact of economic institutions on growth at a crossroads. Acemoglu, Johnson, and Robinson (2001) have shown that economic institutions do matter for a set of 69 developing countries that are distinguished by their colonial history. On the other hand, we are left without guidance as to which - if any - economic institutions of the type discussed in Hall and Jones (1999) matter to the long-run performance of highly developed countries. In the next section we set out to find alternative instruments that are valid for OECD countries, and to test their explanatory power for the Non-OECD sample.

\subsection{The Hierarchy of Institutions Hypothesis}

In search of alternative instruments that control for endogeneity of economic institutions in both the global and the OECD samples, we turn to political institutions. The recent institutions literature has begun to draw a clear distinction between political and economic institutions. Williamson (2000), Acemoglu, Johnson, and Robinson (2005), Acemoglu and Johnson (2005) and Roland (2004), all posit a hierarchy of institutions which we will utilize below. While economic institutions determine economic performance, they are themselves influenced both directly and indirectly by political institutions. The direct effect of political institutions stems, for example, from the concentration of political power in the hands of a malevolent dictator, who dismantles the economic institutions which ensure property rights and equal opportunity. Political institutions may also affect economic institutions indirectly, since they determine the distribution of de jure political power which, in turn, assigns the power to alter economic institutions.

\footnotetext{
${ }^{6}$ Note that the results are confirmed when we control for the small size of the OECD subsample as we bootstrap regressions in section 3.2 .
} 
While political institutions may not affect output directly, constitutions are not written in stone. They change slowly but exhibit great persistence over time, for example, as countries evolve from dictatorships to democracy (and vice versa). Acemoglu, Johnson, and Robinson (2005) argue that political institutions are collective choices; hence the distribution of political power in society is the key determinant of their evolution. Persistence is introduced by those holding political power, who find it in their interest to maintain the status quo even at significant economic cost for society as a whole.

Persson $(2004,2005)$ and Eicher and Schreiber (2005) report empirical evidence for the hierarchy of constitutions, by employing specific constitutional variables as instruments for economic institutions. We follow the same method below. The instruments perform well because they are slow moving and because their direct impact on output is negligible. As a practical matter, this can be established in our regressions (see footnote 10). Glaeser et al (2004) also argue forcefully against a direct link between output and political institutions. Nonetheless, we are careful to examine our results in a robustness section below to confirm that they do not hinge on the assumption that political institutions are entirely exogenous. We allow for the existence of long-term feedback effects from economic outcomes to constitutions in our robustness section. Specifically we introduce alternative political and constitutional instruments that are even less likely to be contaminated by endogeneity.

To examine whether the hierarchy of institutions hypothesis provides successful instruments, we augment the original Hall and Jones (1999) dataset with a number of political institutions provided by the Polity IV database, the World Bank, and the International Country Risk Guide. From Polity IV we select the Constraints on the Chief Executive ("Executive Constraints" below) and Chief Executive Recruitment Regulation ("Executive Recruitment 
Regulation") for 1988 , the year predating our data on income per worker. ${ }^{7}$ For robustness we also include additional Polity IV variables, Legislative and Executive Indices of Electoral Competitiveness in 1975 from the Database on Political Institutions (World Bank), Voice and Accountability from the "Government Matters" database (World Bank), Type and Age of Democracies (as derived by Persson, 2004 from Polity IV), and variables which reflect legal origins (e.g., the German and Scandinavian legal origins significant in La Porta et al 2004, and Levine Loayza and Beck 2000), judicial independence and Constitutional Review (e.g., rigidity of the constitution, judges' influences over the legislative branch) from La Porta et al (2004). The addition of political institutions reduces the size of our baseline dataset from 127 to $114 .^{8}$

Table A2 in the appendix shows that the economic institutions which comprise Hall and Jones' (1999) social infrastructure variable and our proxies for political institutions are quite distinct. Factor analysis on the entire institutional dataset shows that the variables span different dimensions of the dataspace and separate nicely into one economic factor (given by the social infrastructure variables) and two political factors.

Table A1 indicates a high correlation among the political variables. To avoid problems of multicollinearity, we choose Executive Constraints and Executive Recruitment Regulation as our baseline instruments, because these two variables have been used extensively in the literature. ${ }^{9}$ In our robustness section we examine whether our results depend on a particular selection of political institutions. Table 3 reports the results when using our preferred political institutions as instruments in the global sample.

\footnotetext{
${ }^{7}$ Polity IV variables included are the Polity2 index, Competitiveness of Executive Recruitment, Good Democracy, Political Competition, Competitiveness of (Political) Participation, Executive Recruitment Regulation, Executive Electoral Competition, Openness of Executive Recruitment, Regime Durability and Regulation of Participation.

${ }^{8}$ The excluded countries are Barbados, Cape Verde Islands, Hong Kong, Iceland, Luxembourg, Malta, Namibia, Puerto Rico, Reunion, Seychelles, Suriname, Yemen, and Zaire.

9 These particular variables have been featured prominently in empirical institutional assessments of Persson, Tabellini, and Trebbi (2003), Acemoglu and Johnson (2005) Acemoglu, Johnson, and Robinson (2001, 2002),
} 
[Table 3 here]

The 2SLS regression (VII) shows that both instruments are highly significant and that their first stage fit is similar to the benchmark in Hall and Jones (1999) as reported in the 2SLS regression (I). The Over-ID Test is accepted and the political instruments perform strongly as previously shown in different contexts by Persson $(2004,2005)$ and Eicher Schreiber (2005). ${ }^{10}$ The coefficient on economic institutions in the second stage is also similar to the one reported in Hall and Jones (1999). ${ }^{11}$

For robustness we also pair our political institutions with Hall and Jones' (1999) instruments in the 2SLS regression (VIII) to show that the former retain their explanatory power once the additional regressors are included in the first stage. In addition, the C Test (DifferenceIn-Sargan-Test) allows us to test a subset of the original orthogonality conditions in order to establish the exogeneity of our new instruments (to test our instruments against Hall and Jones') in the 2SLS regression (VIII) and is also accepted. Thus we can claim that in the global sample our new instruments perform at least as well as those of Hall and Jones (1999).

While we have found that political institutions are both strong and exogenous instruments for economic institutions, parameter heterogeneity may still be an issue. The fact that institutions matter in the global sample, as shown above, does not provide a guarantee that they work across subsamples. The 2SLS regression (IX) highlights that the effect of political institutions does differ across the samples due to the significant OECD dummy. Nevertheless, in contrast to the 2SLS regression (III), the new instruments do not loose their validity; they remain highly significant and pass the Over-ID Test. The fact that the dummy retains its significance in

Acemoglu et al (2003), Gleaser et al (2004) Djankov et al (2002) and Alfaro, Kalelmi-Ozcan, and Volosovych (2005).

${ }^{10}$ Like Acemoglu, Johnson, and Robinson (2001, 2002), we also used the cruder approach of adding the instruments into the second stage regressions to show that they only influence output through their effect on economic institutions. Indeed, we always find them to be insignificant if added to the second stage. 
the first stage does raise the question however, of whether there is a systematic difference in the influence of political institutions on economic ones in the OECD vs. Non-OECD samples. We explore such potential parameter heterogeneity more thoroughly in Table 4 .

[Table 4 here]

We can examine parameter heterogeneity from two perspectives. First, we split the global sample in regressions (X) and (XII). To avoid loosing information as we move to the subsample analysis, we alternatively examine parameter heterogeneity by adding an interaction term to the global sample which interacts instruments and institutions with the region dummy.

$$
\begin{aligned}
& I^{\star}=\tilde{\gamma}+\bar{X} \tilde{\theta}+\xi D+\imath \bar{X} D+\tilde{\eta} \\
& \log Y / L=\tilde{\alpha}+\beta I^{\bullet}+\zeta D+v I^{\bullet} D+\tilde{\varepsilon}
\end{aligned}
$$

Following Brock and Durlauf (2001) the coefficients on institutions in regressions (XI) and (XIII) are composite coefficient estimates and standard errors for $I^{\star}+I^{\star} D$. The results in regressions (XI) and (XIII) thus take advantage of all information contained in the global dataset, while representing the subsample specific effects of economic institutions on output.

Table 4 presents three important results. First, parameter heterogeneity is confirmed to be of statistic and economic significance, no matter whether the sample is split (regressions X, XII) or not (regressions XI, XIII). In either case, the results are significant and stable across methods in the sense that the coefficients in the interacted, global sample are just about identical to the ones obtained in the subsample estimation. The significance of the region dummies provides clear evidence for parameter heterogeneity.

The second important aspect of Table 4 is that political institutions perform well as instruments across all samples. While only one of the two instruments is significant, there is

\footnotetext{
${ }^{11}$ If we reduce the Hall and Jones (1999) 2SLS regression (1) to the same 114 countries, we obtain a coefficient for economic institutions of 5.46 .
} 
strong evidence that the hierarchy of institutions approach does provide sufficiently strong instruments for economic institutions in each subsample. The adjusted R-square is extremely high across methods and samples (with the exception of first stage in the pure Non-OECD subsample) and the Over-ID Tests are accepted throughout.

The third key implication of Table 4 is that the influence of social infrastructure on output is obtained with considerable precision; it is about three times larger for Non-OECD countries than for OECD countries. This result is akin to our preliminary finding in Table 2 . The smaller coefficient for OECD countries suggests that economic institutions play a smaller, yet equally significant role in determining output in OECD countries as compared to the global or Non-OECD samples. Of course, the income gap between OECD countries (eight-fold in 1970 according to the Penn World tables) is also much smaller than the 30 -fold gap between the richest and the poorest nations in the global sample. For the Non-OECD sample, the importance of the economic institutions, namely, rule of law, bureaucratic quality, corruption, risk of expropriation, government repudiation of contracts, openness to trade, is now significantly greater than in the OECD sample.

The magnitude of the IV-estimate for the impact of economic institutions in the global sample (regression VII) lies between those for the OECD and Non-OECD samples in the 2SLS regressions (XI) and (XIII), which is intuitive. The new instruments thus deliver a similar result across samples as the slopes in our Figure 1 indicated initially: the economic institutions included in the Hall and Jones (1999) social infrastructure index certainly have a larger impact in developing countries. Hence it is no surprise that the coefficient is greatest in the developing country sample, and somewhat lower for OECD countries. The estimate for the combined effect of the two datasets which make up the global sample should then lie in the middle. 
While the size of the coefficient is smaller for the OECD, it is interesting to see that institutions explain a larger share of the variation in OECD income as compared to institutions in the Non-OECD sample. The R squared for the OECD countries ranges from 60 to 76 percent while it is only 52 to 60 percent in the Non-OECD sample. Thus one might be surprised not only how important economic institutions are in the OECD, but also how precisely they forecast income levels in these countries.

While searching for better instruments that are valid for key subsamples of the global dataset, we therefore uncovered important support for the hierarchy of institutions hypothesis in both subsamples and in the global dataset. In the process we come to the surprising conclusion that the type of social infrastructure identified by Hall and Jones (1999) does play a significant role even in advanced OECD economies, which are often seen as representing the gold standard in terms of control of corruption, rule of law and free, well-functioning markets. Interestingly, the impact of such institutions in OECD countries is significant, but about two thirds smaller than in Non-OECD countries.

In the next section, we examine how robust our results are to alternative datasets, alternative measures of economic institution, different groupings of countries, and to specifications that investigate whether current political institutions are truly exogenous.

\section{Robustness}

\subsection{Alternative Instrument Specifications}

An important aspect of our investigation has been the classification of political institutions as exogenous with respect to output levels. However, the income level regressions capture long lasting effects of both political and economic institutional changes that may accumulate over time. While the hierarchy of institutions posits that there is no direct effect of economic outcomes in a particular year on political institutions and constitutions, it is certainly 
possible to imagine that there are feedback effects between economic outcomes and the distribution of power.

We cannot capture evidence for such feedback effects in our sample when we add the political institutions to the second stage (the coefficients on political institutions are insignificant in this case). An alternative method to establish that our instruments are largely exogenous to output in 1989 is to use political institutions that substantially predate 1989 income. In our case we can trace our political institutions back to 1900,88 years prior to our political instruments above. If endogeneity did exist in the case of 1989 income levels and 1988 political institutions, it would arguably be a lot smaller for 1989 income levels and institutions in 1900.

[Table 5 here]

The results for both the OECD and global samples in Table 5 are strong, even with the 89 year lag in political institutions. Both political institutions are highly significant in the global sample, which is reduced to 46 countries due to data constraints, and due to the fact that a number of countries did not exist in 1900. The global estimate for the impact of economic institutions on output is again higher in the global than in the OECD sample. The instruments pass the Over-ID Test for all samples. However, the Non-OECD regression (XVI) is weak overall, with low R squares, and no significant coefficients. While one might expect that the lack of power is due to small sample size, the result is equally weak if we use the Durlauf et al (2001) method of interacting institutions with region dummies to detect parameter heterogeneity while preserving the variation contained in the whole sample. Therefore, the results are due to the particular set of countries that is included in the 24 Non-OECD countries in 1900 . The noticeable difference across all samples as compared to Table 4 is the reduction of the impact of economic institutions on output. 
An alternative robustness check regarding the choice of political variables that we employ above is to examine alternative instruments instead of alternative time periods. Above we used Executive Recruitment Regulation and Executive Constraints due to their prevalence in the institutions literature, and because the data can be traced back to 1900 . Instead of selecting any number of variables among the universe of possible political institutions, Table 6 reports regressions based on the information contained in all 16 political institutions that we identified as potential candidates for instruments. Since the political data is highly correlated (Table A1), we perform factor analysis on the global sample. We identify the two dominant factors (e.g., eigenvalues exceed unity) and report them along with their factor loadings in Table A3. The commonalities among the variables which play important roles in the two factors are such that we label factor 1 Democratic Rules and factor 2 Participation/Stability.

[Table 6 here]

The use of all possible political variables increases the power of the estimations significantly across all samples. In regressions (XVII) to (IXX) the same pattern emerges as above, where the global sample indicates a significant impact of economic institutions on output which lies between the significant estimates for OECD and the Non-OECD countries. With the exception of Participation/Stability for the Non-OECD Sample, all estimates are highly significant, no matter which subsample or political factor we consider. The political instruments are again strong and uncorrelated with the error term in the global as well as the two subsamples. The factor analysis also improves the first stage in terms of significance and fit. Aside from the fact that we are utilizing information contained in all 16 variables, rather than just two, the improved fit might also be a function of the fact that institutions are probably measured with error, which is mitigated by the factor analysis. 
As an additional robustness experiment we also examine specific sets of political institutions that have featured prominently in the political, constitutional, legal and economic institutions analysis of Persson (2004) and La Porta et al (2004). ${ }^{12}$ Persson (2004) uses two main instruments: Form of Democratic Government (whether an established democracy is a presidential or majoritarian system) and Age of Democracy. These two political institutions are employed as instruments in Table 7.

[Table 7 here]

The Persson instruments for political institutions perform well across all subsamples. The Over-ID Test is accepted, the instruments are strong and the fit is good. Note, however, that the estimates of the influence of economic institutions on output levels are reduced for the global and Non-OECD samples. Nonetheless, their magnitudes are still quite similar to the ones obtained with our preferred instruments in Table 4.

A prominent alternative to purely political institutions is provided by La Porta et al (2004), who emphasize the importance of constitutional variables that regulate the legal and judicial system as determinants of economic and political freedoms. We explore the judicial dimension of constitutions in our robustness by using key variables from La Port et al (2004) which relate to Legal Origin, Duration of Supreme Court Judge Tenure, and Judicial Power (whether judges hold power to review constitutionality of laws). ${ }^{13}$

As in the case of our purely political constitutional variables above, we argue that these legal instruments are valid because they are, at best, slow moving over time. In fact, the legal origins can be argued to be just as predetermined as the colonial experience invoked by both Hall and Jones (1999) and Acemoglu, Johnson, and Robinson (2001). Such constitutional variables

\footnotetext{
${ }^{12}$ We thank Torsten Persson for making his dataset available to us. La Porta et al (2004) data is available on their websites.
} 
have usually been in place for long time spans and rarely change. Table 8 provides results using the legal constitutional variables as instruments.

[Table 8 here]

The Legal constitutional instruments perform strongly in the global sample in regression (XXIII). However, in the subsample estimation in regressions (XXIV and XXV), the first stages for OECD and Non-OECD countries are weak and do not perform as well as the political instruments introduced above. Again the OECD subsample coefficient estimate for institutions is smaller than for the global and Non-OECD sample. However, the Non-OECD subsample is measured with considerable error. While the instruments are still passing the Sargan Over-ID Test, only German Legal Origins are actually significant and the institution coefficient in the second stage is significant only at the 10 percent level. Since the Non-OECD sample is reduced to 36 observations only, it is tempting to attribute the weakness of the results to the small sample size. However, Durlauf et al (2001) interaction of a region dummy with the institutions does not solve the issue (not reported here). One might be led to conclude that judicial institutions may be of significance in developed countries, but that their influence is weaker than political institutions for developing countries (see Tables 4 and 6).

\subsection{Outliers and Small Samples}

The OECD sample size is small, which raises the question of whether outliers such as Turkey, Mexico, and Korea influence the results. Turkey and Mexico are not in the World Bank's classification of High Income countries (used above), and we are, after all, interested in the contributions of economic institutions to output in highly developed countries. In this section, we provide outlier robust regression estimates for the first and second stage regressions

\footnotetext{
${ }^{13}$ Note that these instruments do not relate to legal enforcement, which could be argued to be dependent on funds
} 
above which use the OECD country sample. Table 9 reports estimations that attribute less weight to observations that feature large residuals. These regressions are meant to ensure that our results are not driven by unrepresentative outlying observations.

[Table 9]

The outlier robust results in regressions (III'), (X'), (XV') and (XVIII') reinforce our earlier results with coefficients that are in line with the estimates in (III), (X), (XV) and (XVIII). The regressions indicate that our OECD results are not driven by a small subset of unrepresentative countries in the small sample. The Hall and Jones' (1999) specification of instruments in (III') does not perform well as the estimates' significance and magnitudes are greatly reduced. This indicates not only that the instruments fail, but also that the impact of economic institutions on output is estimated with great uncertainty when inadequate instruments are employed in the OECD subsample. The regressions involving political institutions (X', XV' and XVIII') are, however, robust and they exhibit equivalent magnitudes and significance levels as the baseline regressions (X, XV, XVIII). We thus conclude that our results are not negatively impacted by the small sample size or unrepresentative outliers.

The size of the OECD sample also raises doubts about the stability of the estimators. To address this issue we perform bootstrapped standard errors and confidence bands of our OECD estimates.

[Table 10]

Table 10 reports that bootstrapping reduces the power of the first stage across the board, but not to the degree that our essential insights derived above would have to be altered. All instruments that were significant above remain significant, although usually at lower levels. The impact of institutions on output is not impacted, and only in the case of economic institutions from 1900 is 
the significance of the estimate reduced to the 5 percent level. Indeed these exercises highlight just how robust the explanatory power and the stability of the coefficient estimates are across different instruments and estimation methods for the OECD subsample. We thus conclude that our results are robust to alternative specifications of the instruments, as well as to alternative estimation techniques.

\subsection{Alternative Economic Institutions}

All of our results above have so far been conditional on the use of the Hall and Jones' (1999) social infrastructure data as the proxy for economic institutions. The variable is not uncontroversial, because it consists of only a few institutions chosen from a large set of potential candidates. The literature on economic institutions and the empirical indicators that have been employed is surveyed in Acemoglu, Johnson, and Robinson (2005). In this robustness section, we examine whether our results are perhaps related to a specific choice of economic institutions in the second stage.

Following the publication of Hall and Jones (1999), Acemoglu, Johnson, and Robinson (2001, 2002, and 2005) established property rights and checks against government power as an important measure of economic institutions. As an additional robustness check, we seek to examine whether the Acemoglu, Johnson, and Robinson (2001) Risk of Expropriation variable (International Country Risk Guide, averaged over 1985-1995) may also serve as a proxy for economic institutions in our global and OECD samples. ${ }^{14}$ We use the McArthur and Sachs (2000) dataset to expand the original Acemoglu, Johnson, and Robinson (2001) dataset from 69 to over 105 countries (including OECD members).

\footnotetext{
${ }^{14}$ Risk of Expropriation measures differences in institutions due to different types of states and state policies.
} 
Table 11 shows that the hierarchy of institutions hypothesis performs well and that political institutions are strong instruments for Risk of Expropriation across all samples. [Table 11 here]

Both of our political instruments are significant and the Over-Id Test is accepted in all subsamples. Interestingly, different political institutions matter now for different subsamples. In the global sample, both Executive Constraint and Executive Recruitment matter. However in former colonies, only the Executive Constraints matters, while in OECD countries Executive Recruitment is significant. The fit of the first stage is quite high for all samples other than the Non-OECD first stage. The second stage exhibits statistically significant coefficients for economic institutions in all subsamples. Again, the OECD estimates regarding the impact of economic institutions lies below that of the Non-OECD sample.

We can compare the coefficient estimate in the Acemoglu, Johnson, and Robinson baseline regressions (2001, table 4, p. 1386) with our result for the same sample of countries in the 2SLS regression (XXVII). Our political institution instruments perform well for the subgroup of former colonies, and we find that the instruments lead to a very similar coefficient in the second stage as in Acemoglu, Johnson, and Robinson (2001, which is 0.94 in their baseline specification). Even the fit of the first stage is about as good as the 0.27 reported in Acemoglu, Johnson, and Robinson (2001). We can conclude that the political instruments are strong not only across country samples, but also across different proxies for the economic institutions.

\section{Conclusion}

We examine the impact of economic institutions on economic performance across OECD and Non-OECD subsamples. The goal is to ascertain if the results derived from studies using global datasets readily translate to high income countries. While the relationship between 
economic institutions and economic outcomes has been established empirically for developing countries and for global datasets, it has not been analyzed for the countries that represent the gold standard of institutions today.

Analysis of institutions among developed countries is inhibited by the absence of established instruments. Popular instruments in the institutions literature are shown to be relevant only for the global sample or for developing countries. We hypothesize that the notion of the hierarchy of institutions may provide sufficiently strong instruments and utilize political/constitutional institutions to serve as instruments for economic institutions. To do so, we show that they lead to very similar results when applied to the same groups of countries as the established instruments. The political institutions also pass all relevant statistical tests when they are employed only in the OECD subsample. We find substantial evidence of parameter heterogeneity in economic institutions: the impact of Hall and Jones' (1999) economic institutions on income in OECD countries is only one third of the effect that the same institutions exert in Non-OECD countries.

Our results are robust to different specifications regarding time periods, different sets of political variables, and to a number of different samples splits. Most surprising is perhaps, that the established instruments which perform strongly in the global sample, such as Latitude and European Languages, do not perform in either the OECD or the Non-OECD sample. 


\section{References}

Acemoglu, D., S. Johnson and J. A. Robinson, (2001). "The Colonial Origins of Comparative Development: An Empirical Investigation," American Economic Review 91, 1369-1401

- (2002). "Reversal of Fortune: Geography and Institutions in the Making of the Modern World of Income Distribution." Quarterly Journal of Economics 117, 1231 - 1294. -- (2005). "Institutions As the Fundamental Cause of Long-Run Economic Growth", forthcoming in Handbook of Economic Growth, editors Philippe Aghion and Stephen Durlauf.

Acemoglu, D., S. Johnson, J. A. Robinson and Y. Thaicharoen, (2003). "Institutional Causes, Macroeconomic Symptoms: Volatility, Crises and Growth," Journal of Monetary Economics 50, 49-123.

Acemoglu, D. and S. Johnson (2005). "Unbundling Institutions," Journal of Political Economy, forthcoming.

Alfaro, L., S. Kalelmi-Ozcan, and V. Volosovych (2005). "Capital Flows in a Globalized World: The Role of Policies and Institutions," in S. Edwards, ed., Capital Controls and Capital Flows in Emerging Economies: Policies, Practices and Consequences, National Bureau of Economic Research, forthcoming.

Bassanini, A., P. Hemmings and S. Scarpetta, (2001). "Economic Growth: The Role of Policies and Institutions. Panel Data. Evidence from OECD Countries," OECD Economics Department Working Paper 283, OECD Economics Department

Boeri, T., G. Nicoletti and S. Scarpetta, (2000). "Regulation And Labour Market Performance," CEPR Discussion Papers 2420, London, Centre for Economic Policy Research.

Brock, W. and S. Durlauf, (2001). "Growth Empirics and Reality," The World Bank Economic Review 15, 229-272.

Caselli, F., (2005). "Accounting for Cross-Country Income Differences," forthcoming in Handbook of Economic Growth, editors Philippe Aghion and Stephen Durlauf

Carlina, W. and C. Mayerb, (2003). "Finance, Investment, and Growth," Journal of Financial Economics 69, 191-226.

De Grauwe, P. and F. Skudelny, (1999). "Social Conflict and Growth in Euroland," CEPR Discussion Paper no. 2186, London, Centre for Economic Policy Research.

Djankov, S., R. La Porta, F. Lopez-de-Silanes, and A. Shleifer (2002). "The Regulation of Entry," Quarterly Journal of Economics 117, 1-37.

Eicher, T.S. and Schreiber, T. (2005), “Institutions And Growth: Time Series Evidence from Natural Experiments," mimeo University of Washington.

Engerman, S. L., and K. L. Sokoloff, (1997). "Factor Endowments, Institutions, and Differential Paths of Growth among New World Economies," in S. Haber, ed., How Latin America Fell Behind, Stanford University Press.

Frankel, J. A. and D. Romer (1996). "Trade and Growth: An Empirical Investigation," NBER WP 5476.

Frankel, J. A. and D. Romer. (1999). "Does Trade Cause Growth?”, American Economic Review 89, 379-399.

Glaeser E., La Porta, R., Lopes-de-Silanes, F. and Shleifer, A. (2004). "Do Institutions Cause Growth?", Journal of Economic Growth 9, 271-303.

Hall, R. E. and C. I. Jones, (1999). "Why Do Some Countries Produce So Much More Output per Worker than Others?", Quarterly Journal of Economics 114, 83-116. 
La Porta, R., López-de-Silanes, F., Pop-Eleches, C., and Shleifer, A., (2004). "Judicial Checks and Balances," Journal of Political Economy 112, 445-470.

McArthur, J.W. and J.D. Sachs, (2001). "Institutions and Geography: Comment on Acemoglu, Johnson and Robinson (2000)", NBER Working Paper 8114.

Nickell, S., L. Nunziata and W. Ochel, (2005). "Unemployment in the OECD since the 1960s: What do we know?" Economic Journal 115, 1-27

Nicoletta, G. and S. Scarpetty, (2003) "Regulation, Productivity and Growth: OECD Evidence", Economic Policy 36, 9-72.

Persson, T., (2004). "Consequences of Constitutions," Journal of the European Economic Association 2, 139-152.

Persson, T., (2005). "Forms of Democracy, Policy and Economic Development", mimeo, Stockholm University.

Persson, T., G. Tabellini and F. Trebbi, (2003). "Electoral Rules and Corruption," Journal of the European Economic Association 1, 958-989.

Rodrik, D., Subramanian, A., and Trebbi, F. (2004). "Institutions Rule: The Primacy of Institutions Over Geography and Integration in Economic Development," Journal of Economic Growth 9, 131-165.

Roland, G., (2004). "Understanding Institutional Change: Fast-Moving and Slow-Moving Institutions," Studies in Comparative International Development 38, 109-131.

Schneider, F. and A. F. Wagner, (2001). "Institutions of Conflict Management and Economic Growth in the European Union," Kyklos 54, 509-532

Williamson, O. E., (2000), "The New Institutional Economics: Taking Stock, Looking A head," The Journal of Economic Literature 38, 595-613. 
Figure 1

Institutions and Economic Performance

OECD and Non-OECD Countries

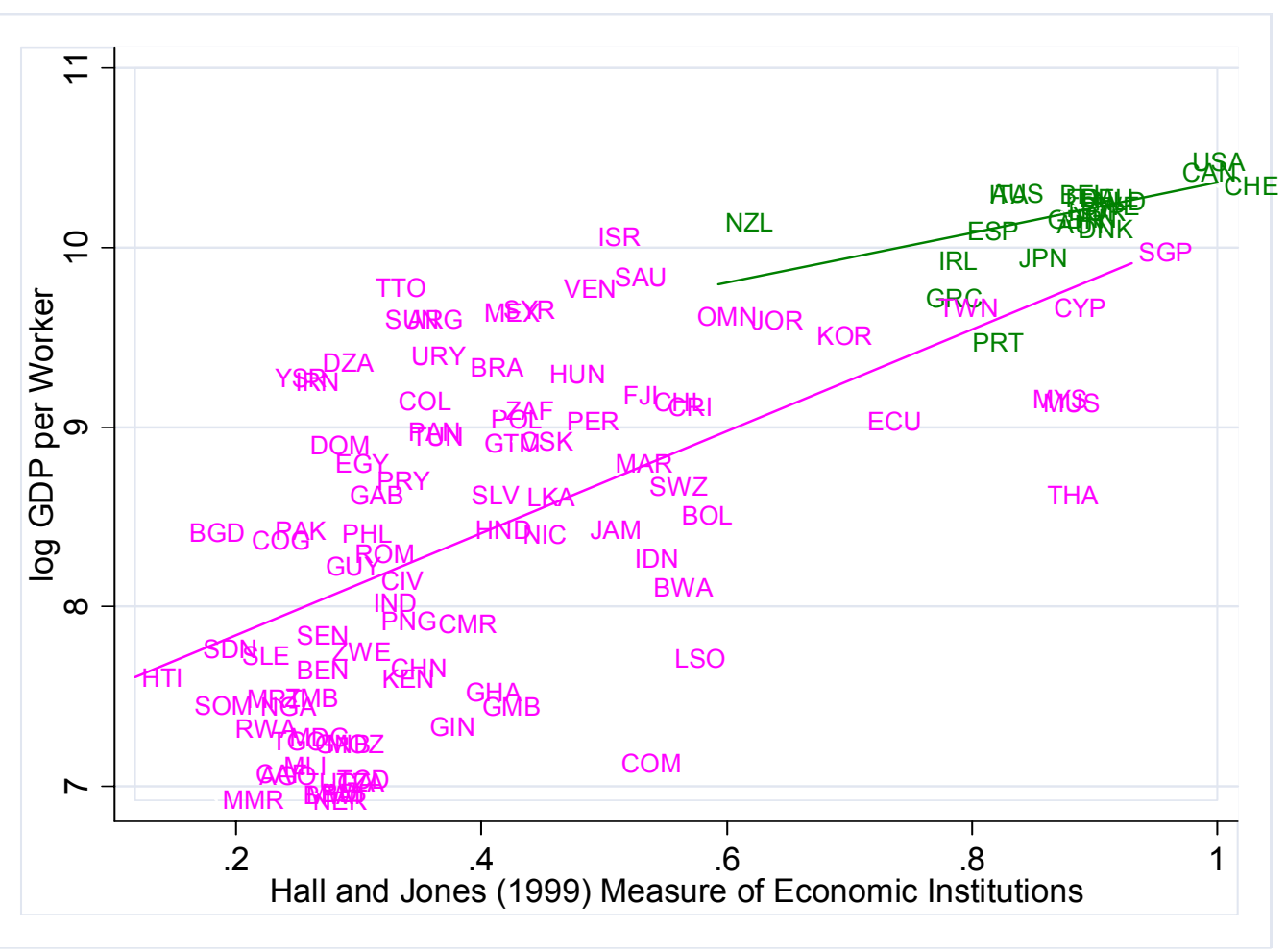

Data source: Hall and Jones (1999) 
Table 1

Explanatory Power of Institutions and Instruments

First Evidence for Parameter Heterogeneity (2SLS)

\begin{tabular}{|l|cccc|}
\hline & \multicolumn{2}{|c}{ (I) } & \multicolumn{2}{c|}{ (II) } \\
& Hall and Jones (1999) & \multicolumn{2}{c|}{ Global Sample } \\
& Institutions & Y/L & Institutions & Y/L \\
\hline \hline \multirow{2}{*}{ Institutions } & & $5.085^{* * *}$ & & $5.580^{* * *}$ \\
OECD Dummy & & $(0.545)$ & & $(1.268)$ \\
& & & $0.340^{* * *}$ & -0.583 \\
English Language & 0.136 & & $(0.052)$ & $(0.522)$ \\
Fraction & $(0.092)$ & & $(0.054$ & \\
European Language & $0.170^{* * *}$ & & $0.098^{* *}$ & \\
Fraction & $(0.056)$ & & $(0.049)$ & \\
Implied Trade & $0.044 *$ & & $0.061 * * *$ & \\
Share & $(0.025)$ & & $(0.022)$ & \\
& & & 0.001 & \\
Latitude & $0.004 * * *$ & & $(0.001)$ & \\
& $(0.001)$ & & 127 & 127 \\
\hline N & 127 & 127 & 0.48 & 0.35 \\
Adjusted R-squared & 0.30 & 0.41 & & $0.044 * *$ \\
Over-ID Test & & 0.243 & & \\
\hline
\end{tabular}

Notes: Not reported: intercept; standard errors in parentheses. Significance at the 10, 5 and 1 percent levels are indicated by $*, * *, * * *$, respectively. The First stage always includes the fraction of the population speaking English or another European Language (English Fraction and European Fraction), the Implied Trade Share from a gravity trade equation (Implied Trade Share) and the geographical Latitude of a country. The second stage regresses the log of income per worker on the instrumented economic institutional variable. The 2SLS regression (II) adds a Dummy for OECD membership in 1999 to both stages. Over-ID Test is the p-value of the Hansen-Sargan Test statistic of overidentifying restrictions of all (but one) Instrument, the joint null being that the instruments are valid. The "»"superscript indicates instrumented variables. 
Table 2

Performance of Institutions and Instruments

Power of Instruments Across Subsamples (2SLS)

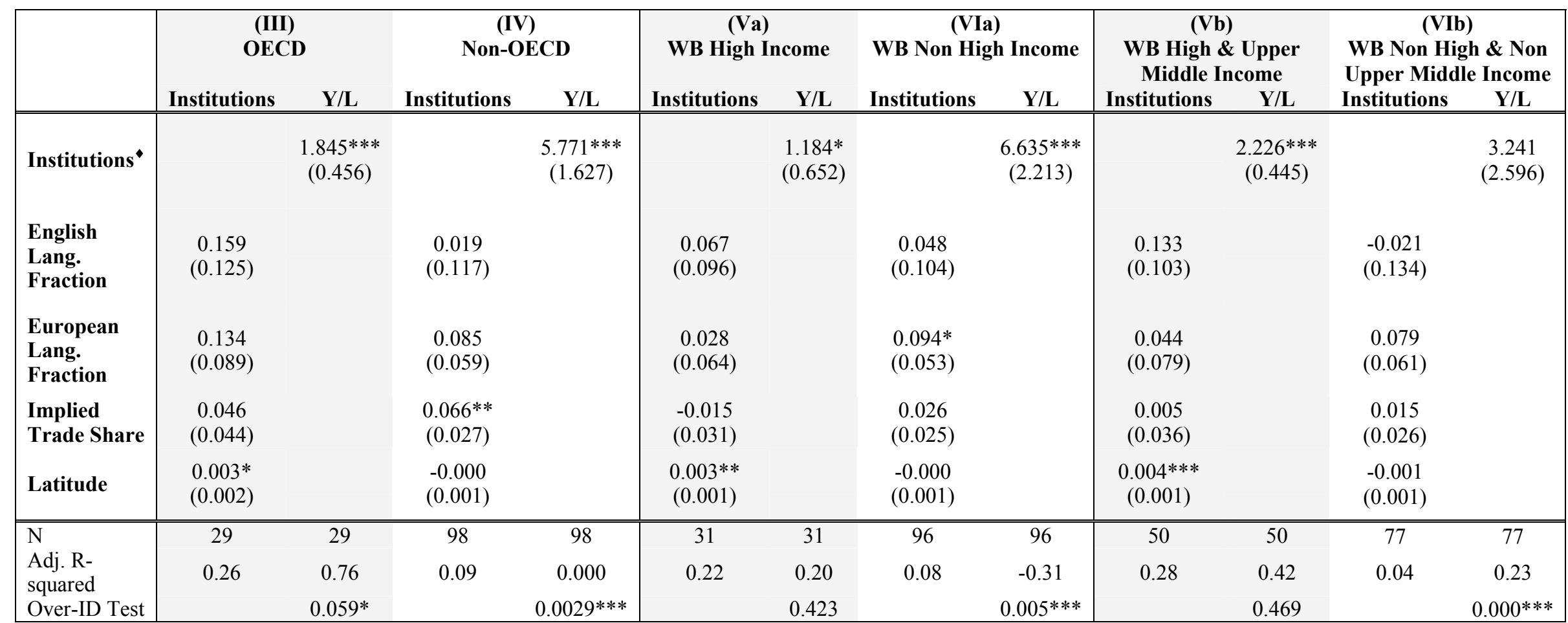

Notes: Not reported: intercept; standard errors in parentheses. . Significance at the 10, 5 and 1 percent levels are indicated by $*, * * * * *$, respectively. First stage always includes the fraction of the population speaking English or another European Language (English Fraction and European Fraction), the Implied Trade Share from a gravity trade equation (Implied Trade Share) and the geographical Latitude of a country; Second stage regresses the log of income per worker only on the instrumented economic institutional variable. Overid Test is the p-value of the Hansen-Sargan Test statistic of overidentifying restrictions of all (but one) Instrument, the joint null being that the instruments are valid. Columns (V) and (VI) split the sample according to the World bank's classifications of High, Medium and Low Income countries. The " "superscript indicates instrumented variables. 
Table 3

Institutions and New Instruments:

The Hierarchy of Institutions (2SLS)

\begin{tabular}{|c|c|c|c|c|c|c|}
\hline & \multicolumn{2}{|c|}{$\begin{array}{c}\text { (VII) } \\
\text { Global Sample }\end{array}$} & \multicolumn{2}{|c|}{$\begin{array}{c}\text { (VIII) } \\
\text { Global Sample }\end{array}$} & \multicolumn{2}{|c|}{$\begin{array}{c}\text { (IX) } \\
\text { Global Sample }\end{array}$} \\
\hline Institutions & & $\begin{array}{l}4.870^{* * *} \\
(0.503)\end{array}$ & & $\begin{array}{c}4.871 * * * \\
(0.455)\end{array}$ & & $\begin{array}{c}5.789 * * * \\
(1.020)\end{array}$ \\
\hline OECD Dummy & & & & & $\begin{array}{c}0.300 * * * \\
(0.043)\end{array}$ & $\begin{array}{l}-0.628 \\
(0.441)\end{array}$ \\
\hline Executive Recruitment Regulation & $\begin{array}{c}0.091 * * \\
(0.042)\end{array}$ & & $\begin{array}{c}0.067 \\
(0.041)\end{array}$ & & $\begin{array}{c}0.109 * * * \\
(0.036)\end{array}$ & \\
\hline $\begin{array}{l}\text { English Language } \\
\text { Fraction }\end{array}$ & & & $\begin{array}{c}0.079 \\
(0.086)\end{array}$ & & & \\
\hline Latitude & & & $\begin{array}{c}0.002 * * * \\
(0.001)\end{array}$ & & & \\
\hline $\mathrm{N}$ & 114 & 114 & 114 & 114 & 114 & 114 \\
\hline Adjusted R-squared & 0.37 & 0.45 & 0.45 & 0.45 & 0.57 & 0.33 \\
\hline Over-ID Test & & 0.355 & & 0.125 & & 0.831 \\
\hline $\begin{array}{l}\text { Over-ID C-Test for Political } \\
\text { Institutions subset }\end{array}$ & & & & 0.104 & & \\
\hline
\end{tabular}

Notes: Not reported: intercept; standard errors in parentheses. Significance at the 10,5 and 1 percent levels are indicated by $*, * *, * * *$, respectively. The First stage always includes Constraints on the Executive (Executive Constraints) and Regulation of Chief Executive Recruitment (Executive Recruitment Regulation). The fraction of the population speaking English or another European Language (English Fraction and European Fraction), the Implied Trade Share from a gravity trade equation (Implied Trade Share) and the geographical Latitude of a country and finally a dummy indicating OECD membership as of 1999 are subsequently added; Second stage regresses the log of income per worker only on the instrumented economic institutional variable. The Over-ID Test reports the p-value of the Hansen-Sargan Test statistic of overidentifying restrictions of all (but one) Instrument, the joint null being that the instruments are valid. Over-ID, C-Test is the p-value of the C-statistic when testing the over-identifying restriction for the two political instruments visà-vis the established ones. The "»"superscript indicates instrumented variables. 
Table 4

Hierarchy of Institutions and Parameter Heterogeneity (2SLS)

\begin{tabular}{|c|c|c|c|c|c|c|c|c|}
\hline \multirow[t]{2}{*}{ 、 } & \multicolumn{2}{|c|}{$\begin{array}{c}(X) \\
\text { OECD }\end{array}$} & \multicolumn{2}{|c|}{$\begin{array}{c}\text { (XI) } \\
\text { OECD } \\
\text { (global sample with } \\
\text { interaction terms) }\end{array}$} & \multicolumn{2}{|c|}{$\begin{array}{c}\text { (XII) } \\
\text { Non-OECD }\end{array}$} & \multicolumn{2}{|c|}{$\begin{array}{c}\text { (XIII) } \\
\text { Non-OECD } \\
\text { (global sample with } \\
\text { interaction terms) }\end{array}$} \\
\hline & Institutions & $\mathbf{Y} / \mathbf{L}$ & Institutions & $\mathbf{Y} / \mathbf{L}$ & Institutions & $\mathbf{Y} / \mathbf{L}$ & Institutions & $\mathbf{Y} / \mathbf{L}$ \\
\hline Institutions & & $\begin{array}{l}2.317 * * * \\
(0.257)\end{array}$ & & $\begin{array}{l}2.317 * * * \\
\quad(.806)\end{array}$ & & $\begin{array}{l}7.529 * * * \\
(1.849)\end{array}$ & & $\begin{array}{c}7.529 * * * \\
(1.139)\end{array}$ \\
\hline OECD Dummy & & & $\begin{array}{c}-0.473 * * \\
(0.219)\end{array}$ & $\begin{array}{l}2.664 * * * \\
(0.762)\end{array}$ & & & & \\
\hline Non - OECD Dummy & & & & & & & $\begin{array}{c}0.473 * * \\
(0.219)\end{array}$ & $\begin{array}{c}-2.664 * * * \\
(0.762)\end{array}$ \\
\hline Executive Constraints & $\begin{array}{c}0.027 \\
(0.027)\end{array}$ & & $\begin{array}{c}0.005 \\
(0.010)\end{array}$ & & $\begin{array}{c}0.005 \\
(0.011)\end{array}$ & & $\begin{array}{c}0.027 \\
(0.045)\end{array}$ & \\
\hline $\begin{array}{l}\text { Executive Recruitment } \\
\text { Regulation }\end{array}$ & $\begin{array}{c}0.323 * * * \\
(0.086)\end{array}$ & & $\begin{array}{l}0.085 * * \\
(0.035)\end{array}$ & & $\begin{array}{c}0.085 * * \\
(0.038)\end{array}$ & & $\begin{array}{c}0.323 * * \\
(0.144)\end{array}$ & \\
\hline $\mathrm{N}$ & 27 & 27 & 114 & 114 & 87 & 87 & 114 & 114 \\
\hline Adjusted R-squared & 0.79 & 0.76 & 0.60 & 0.59 & 0.14 & 0.52 & 0.60 & 0.59 \\
\hline Over-ID Test & & 0.584 & & NA & & 0.974 & & NA \\
\hline
\end{tabular}

Notes: Not reported: intercept; standard errors in parentheses. Significance at the 10, 5 and 1 percent levels are indicated by $*, * *, * * *$, respectively. The First stage always includes Constraints on the Executive (Executive Constraints) and Regulation of Chief Executive Recruitment (Executive Recruitment). For columns (XI) and (XIII) the specified dummy (OECD or Non-OECD) is included as well as interactions of that dummy with Executive Constraints and Regulation of Chief Executive Recruitment are added in first stage. The Second stage includes the predicted institutions value as well as an interacted predicted institutions value with a (Non-) OECD dummy plus the dummy. The reported coefficients for institutions in the second stage the composite effects of (Institutions ${ }^{\star}+$ Institutions ${ }^{\star} \cdot$ Dummy). Standard errors for that effect are calculated with the delta method. The Over-ID Test is the p-value of the Hansen-Sargan Test statistic of overidentifying restrictions of all (but one) Instrument, the joint null being that the instruments are valid. The " "superscript indicates instrumented variables. 
Table 5:

Instrument Robustness

Political Institutions in 1900

\begin{tabular}{|c|c|c|c|c|c|c|}
\hline & \multicolumn{2}{|c|}{$\begin{array}{l}\text { (XIV) } \\
\text { Global }\end{array}$} & \multicolumn{2}{|l|}{$\begin{array}{c}\text { (XV) } \\
\text { OECD }\end{array}$} & \multicolumn{2}{|c|}{$\begin{array}{c}\text { (XVI) } \\
\text { Non-OECD }\end{array}$} \\
\hline Institutions $_{1989}$ & & $\begin{array}{c}2.657 * * * \\
(0.378)\end{array}$ & & $\begin{array}{l}1.790 * * * \\
(0.41)\end{array}$ & & $\begin{array}{c}1.284 \\
(2.607)\end{array}$ \\
\hline $\begin{array}{l}\text { Executive } \\
\text { Constraints } 1900\end{array}$ & $\begin{array}{l}0.057 * * * \\
(0.011)\end{array}$ & & $\begin{array}{l}0.050 * * * \\
(0.015)\end{array}$ & & $\begin{array}{c}0.013 \\
(0.018)\end{array}$ & \\
\hline $\begin{array}{l}\text { Executive Recruitment } \\
\text { Regulation } 1900\end{array}$ & $\begin{array}{l}0.110 * * \\
(0.043)\end{array}$ & & $\begin{array}{l}0.129 \\
(0.108)\end{array}$ & & $\begin{array}{c}0.046 \\
(0.042)\end{array}$ & \\
\hline $\mathrm{N}$ & 46 & 46 & 22 & 22 & 24 & 24 \\
\hline Adjusted R-squared & 0.52 & 0.56 & 0.43 & 0.69 & 0.08 & 0.02 \\
\hline Over-ID Test & & 0.528 & & 0.116 & & 0.540 \\
\hline
\end{tabular}

Notes: Not reported: intercept; standard errors in parentheses. Significance at the 10,5 and 1 percent levels are indicated by $*, * *, * * *$, respectively. The First stage always includes Constraints on the Executive (Executive Constraints) and Regulation of Chief Executive Recruitment (Executive Recruitment) in 1900. Economic Institutions are the ones in 1989. Early political institutions data limitations reduce the sample size to 112 for the global sample. The "•"superscript indicates instrumented variables. 
Table 6

Instrument Robustness

Factor Analysis: All Political Variables

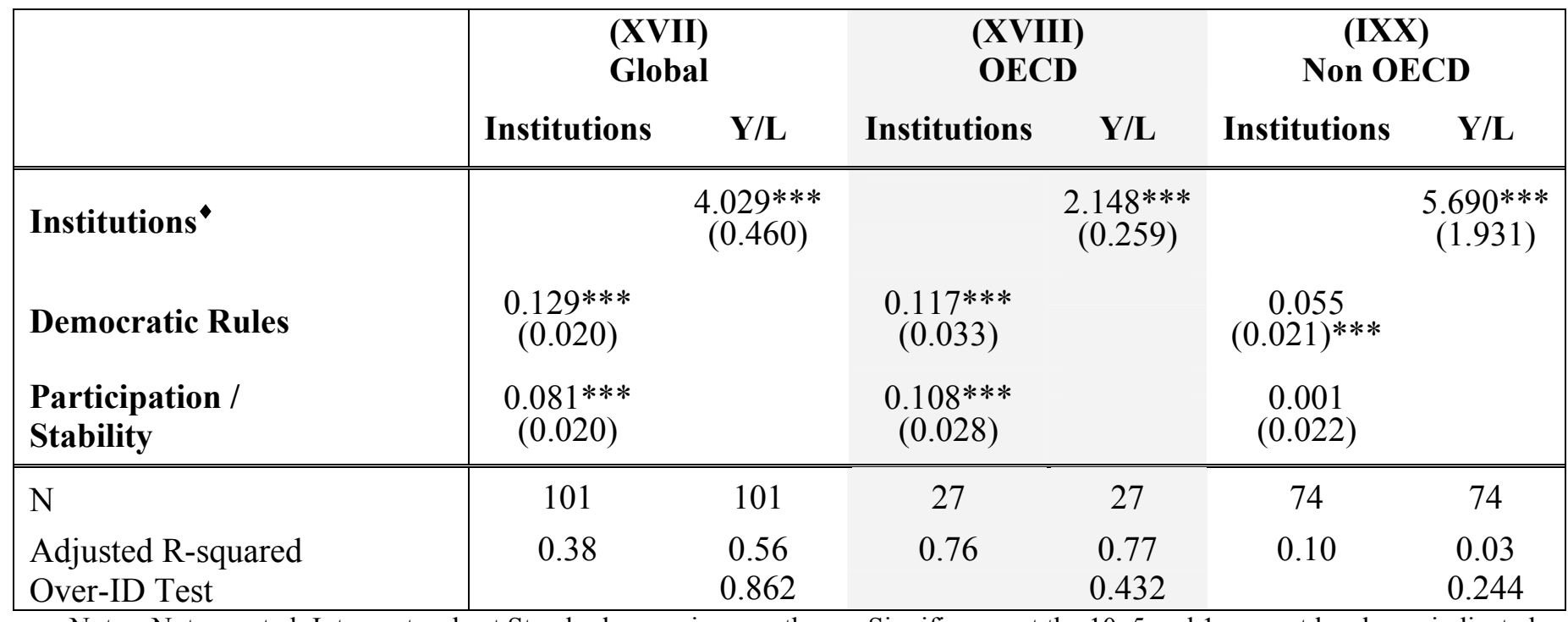

Notes: Not reported: Intercept; robust Standard errors in parentheses. Significance at the 10,5 and 1 percent levels are indicated by *,**,***, respectively. Democratic Rules and Participation/Stability are the first two rotated factors from a factor analysis on all political variables (Good Democracy, Polity2, Regime Durability, Executive Recruitment Regulation, Competitiveness of Executive Recruitment, Openness of Executive Recruitment, Executive Constraints, Regulation of Participation, Competitiveness of Participation, Executive Recruitment, Political Competition, Democratic Accountability, Legislative Electoral Competition, Executive Electoral Competition, Voice and Accountability, Political Stability). The "•"superscript indicates instrumented variables. 
Table 7

Instrument Robustness

Persson's (2004) Political Institutions

\begin{tabular}{|c|c|c|c|c|c|c|}
\hline & \multicolumn{2}{|c|}{$\begin{array}{c}\text { (XX) } \\
\text { Global }\end{array}$} & \multicolumn{2}{|c|}{$\begin{array}{l}\text { (XXI) } \\
\text { OECD }\end{array}$} & \multicolumn{2}{|c|}{$\begin{array}{c}\text { (XXII) } \\
\text { Non OECD }\end{array}$} \\
\hline & Institutions & $\mathbf{Y} / \mathbf{L}$ & Institutions & $\mathbf{Y} / \mathbf{L}$ & Institutions & $\mathbf{Y} / \mathbf{L}$ \\
\hline Institutions & & $\begin{array}{l}3.901 * * * \\
(0.351)\end{array}$ & & $\begin{array}{l}2.627 * * * \\
(0.385)\end{array}$ & & $\begin{array}{l}3.291 * * * \\
(0.834)\end{array}$ \\
\hline $\begin{array}{l}\text { Form of Democratic } \\
\text { Government }\end{array}$ & $\begin{array}{l}0.224 * * * \\
(0.034)\end{array}$ & & $\begin{array}{c}0.050 \\
(0.084)\end{array}$ & & $\begin{array}{l}0.209 * * * \\
(0.042)\end{array}$ & \\
\hline Age of Democracy & $\begin{array}{l}0.541 * * * \\
(0.077)\end{array}$ & & $\begin{array}{l}0.430 * * * \\
(0.107)\end{array}$ & & $\begin{array}{l}0.280^{*} \\
(0.149)\end{array}$ & \\
\hline $\begin{array}{l}\mathrm{N} \\
\text { Adjusted R-squared } \\
\text { Over-ID Test }\end{array}$ & $\begin{array}{l}112 \\
0.58\end{array}$ & $\begin{array}{c}112 \\
0.59 \\
0.265\end{array}$ & $\begin{array}{c}27 \\
0.40\end{array}$ & $\begin{array}{c}27 \\
0.72 \\
0.664\end{array}$ & $\begin{array}{c}85 \\
0.29\end{array}$ & $\begin{array}{c}85 \\
0.33 \\
0.029 * *\end{array}$ \\
\hline
\end{tabular}

Notes: Not reported: intercept; standard errors in parentheses. Significance at the 10, 5 and 1 percent levels are indicated by $* * *, * * *$, respectively. First stage always includes Parliamentary Democracy and Age of Democracy from Persson (2005). The instrumented institutions is Hall and Jones' (1999) social infrastructure and income per worker is from their dataset as well. Adding the Persson (2004) data reduces the sample size to 112 for the global sample. The " "superscript indicates instrumented variables. 
Table 8

Instrument Robustness

La Porta et al (2004) Judicial Institutions

\begin{tabular}{|c|c|c|c|c|c|c|}
\hline & \multicolumn{2}{|c|}{$\begin{array}{c}\text { (XXIII) } \\
\text { Global }\end{array}$} & \multicolumn{2}{|c|}{$\begin{array}{c}\text { XXIV }) \\
\text { OECD }\end{array}$} & \multicolumn{2}{|c|}{$\begin{array}{c}\text { (XXV) } \\
\text { Non OECD }\end{array}$} \\
\hline & Institutions & $\mathbf{Y} / \mathbf{L}$ & Institutions & $\mathbf{Y} / \mathbf{L}$ & Institutions & $\mathbf{Y} / \mathbf{L}$ \\
\hline Institutions & & $\begin{array}{c}2.790 * * * \\
(0.540)\end{array}$ & & $\begin{array}{l}1.397 * * \\
(0.611)\end{array}$ & & $\begin{array}{l}2.730^{*} \\
(1.657)\end{array}$ \\
\hline $\begin{array}{l}\text { German legal } \\
\text { Origin }\end{array}$ & $\begin{array}{c}0.364 * * * \\
(0.101)\end{array}$ & & $\begin{array}{l}0.186^{*} \\
(0.096)\end{array}$ & & $\begin{array}{l}0.354 * \\
(0.197)\end{array}$ & \\
\hline $\begin{array}{l}\text { Scandinavian } \\
\text { Legal Origin }\end{array}$ & $\begin{array}{l}0.335 * * * \\
(0.120)\end{array}$ & & $\begin{array}{c}0.099 \\
(0.085)\end{array}$ & & $\mathrm{NA}^{*}$ & \\
\hline $\begin{array}{l}\text { Supreme Court } \\
\text { Judge Tenure }\end{array}$ & $\begin{array}{l}0.128 * * \\
(0.056)\end{array}$ & & $\begin{array}{l}0.196 * \\
(0.104)\end{array}$ & & $\begin{array}{c}0.061 \\
(0.053)\end{array}$ & \\
\hline $\begin{array}{l}\text { Constitutional } \\
\text { Review }\end{array}$ & $\begin{array}{l}-0.057 \\
(0.119)\end{array}$ & & $\begin{array}{c}0.003 \\
(0.116)\end{array}$ & & $\begin{array}{l}-0.091 \\
(0.137)\end{array}$ & \\
\hline $\mathrm{N}$ & 60 & 60 & 24 & 24 & 36 & 36 \\
\hline Adj. R-squared & 0.30 & 0.61 & 0.24 & 0.59 & 0.14 & 0.27 \\
\hline Over-ID Test & & 0.670 & & 0.722 & & 0.466 \\
\hline
\end{tabular}

Notes: Not reported: intercept; standard errors in parentheses. Significance at the 10,5 and 1 percent levels are indicated by $*, * *, * * *$, respectively. First stages include only the 4 variables from La Porta et al (2004) as specified in the main text. The instrumented institutions is Hall and Jones' (1999) social infrastructure and income per worker is from their dataset as well. The use of the La Porta et al (2004) dataset reduces the sample size to 60 for the global sample. * Dropped due to collinearity. The "»"superscript indicates instrumented variables. 
Table 9

Outlier Robust Estimation

OECD Regressions

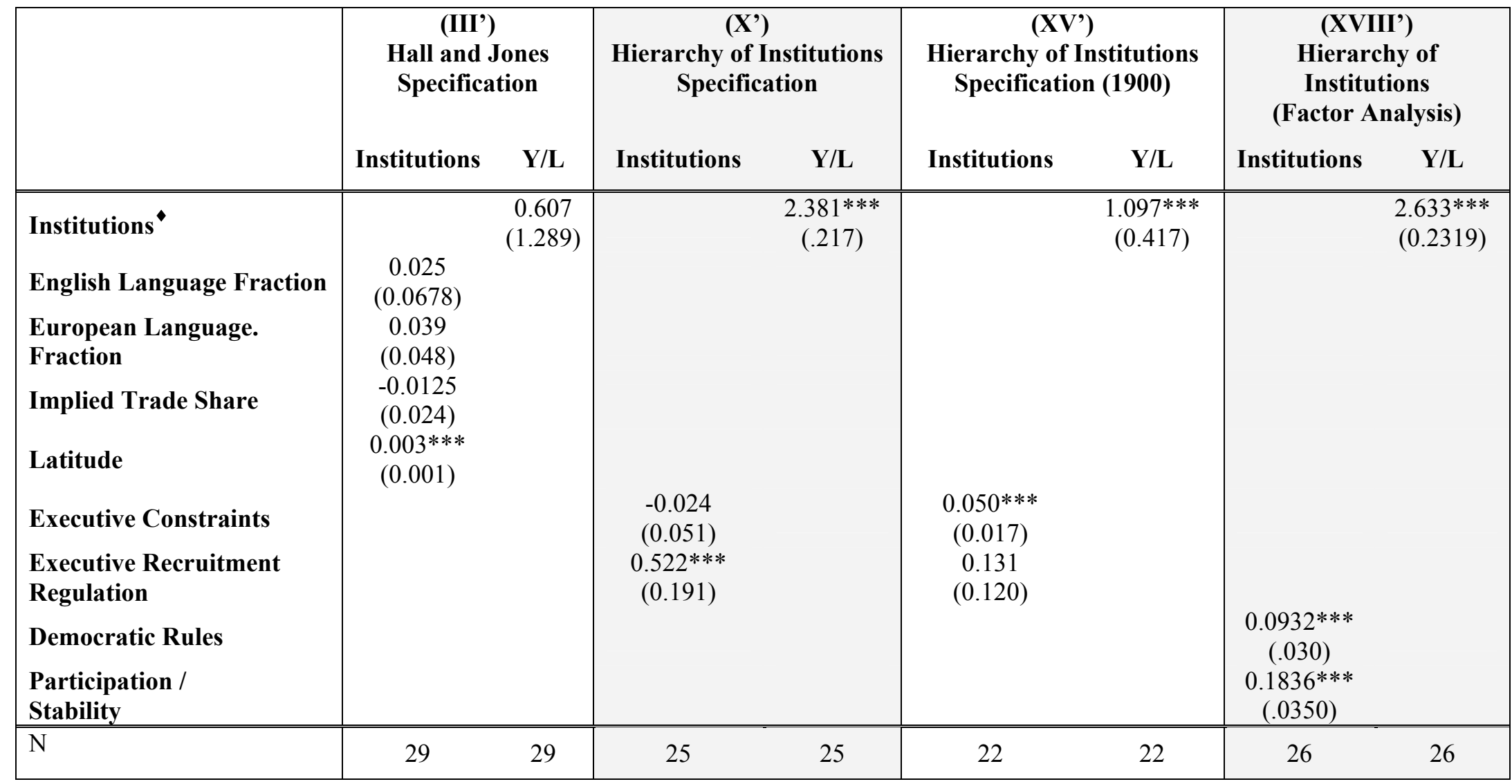

Notes: Not reported: intercept; standard errors in parentheses. Significance at the 10,5 and 1 percent levels are indicated

by $* * *, * * *$, respectively. The number of observations in the 2 SLS regression (X') is reduced to 25 as compared to 27

in $(X)$ because the outlying observation Turkey and South Korea are dropped in the robust regression. R-square and

Over-ID Tests are not applicable with these methods. The " $\bullet$ "superscript indicates instrumented variables. 
Table 10

Bootstrapped Results

OECD Regressions

\begin{tabular}{|c|c|c|c|c|c|c|c|c|}
\hline & \multicolumn{2}{|c|}{$\begin{array}{c}\text { (III') } \\
\text { Hall and Jones } \\
\text { Specification }\end{array}$} & \multicolumn{2}{|c|}{$\begin{array}{c}\left(X^{\prime \prime}\right) \\
\text { Hierarchy of Institutions } \\
\text { Specification }\end{array}$} & \multicolumn{2}{|c|}{$\begin{array}{c}\left(X V^{\prime \prime}\right) \\
\text { Hierarchy of Institutions } \\
\text { Specification (1900) }\end{array}$} & \multicolumn{2}{|c|}{$\begin{array}{c}\text { (XVII'”) } \\
\text { Hierarchy of } \\
\text { Institutions } \\
\text { (Factor Analysis) }\end{array}$} \\
\hline & Institutions & $\mathbf{Y} / \mathbf{L}$ & Institutions & $\mathbf{Y} / \mathbf{L}$ & Institutions & $\mathbf{Y} / \mathbf{L}$ & Institutions & $\mathbf{Y} / \mathbf{L}$ \\
\hline Institutions & . & $\begin{array}{l}1.845^{* * *} * \\
(0.558)\end{array}$ & & $\begin{array}{c}2.317 * * * \\
(0.334)\end{array}$ & & $\begin{array}{l}1.790 * * \\
(0.734)\end{array}$ & & $\begin{array}{c}2.148 * * * \\
(.3979)\end{array}$ \\
\hline $\begin{array}{l}\text { English Language } \\
\text { Fraction }\end{array}$ & $\begin{array}{c}0.159 \\
(0.181)\end{array}$ & & & & & & & \\
\hline $\begin{array}{l}\text { European Language } \\
\text { Fraction }\end{array}$ & $\begin{array}{l}0.133 * \\
(0.079)\end{array}$ & & & & & & & \\
\hline Implied Trade Share & $\begin{array}{c}0.046 \\
(0.072)\end{array}$ & & & & & & & \\
\hline Latitude & $\begin{array}{l}0.003 * \\
(0.002)\end{array}$ & & & & & & & \\
\hline $\begin{array}{l}\text { Executive } \\
\text { Constraints }\end{array}$ & & & $\begin{array}{c}.0271 \\
(0.040)\end{array}$ & & $\begin{array}{c}0.050 * * \\
(0.022)\end{array}$ & & & \\
\hline $\begin{array}{l}\text { Executive } \\
\text { Recruitment } \\
\text { Regulation }\end{array}$ & & & $\begin{array}{c}0.323 * * \\
(0.153)\end{array}$ & & $\begin{array}{c}0.129 \\
(0.098)\end{array}$ & & & \\
\hline Democratic Rules & & & & & & & $\begin{array}{l}0.117 * * \\
(.05386)\end{array}$ & \\
\hline $\begin{array}{l}\text { Participation / } \\
\text { Stability }\end{array}$ & & & & & & & $\begin{array}{l}0.108 * * \\
(.04893)\end{array}$ & \\
\hline $\mathrm{N}$ & 29 & 29 & 27 & 27 & 22 & 22 & 27 & 27 \\
\hline
\end{tabular}

Notes: Not reported: Intercept; Bootstrapped standard errors in parentheses (from 10000 replications). Significance at the

10,5 and 1 percent levels are indicated by $*, * *, * *$, respectively. R-square and Over-ID Tests are not applicable with these methods. The " $"$ superscript indicates instrumented variables. 
Table 11

Hierarchy of Institutions in Alternative Datasets

Risk of Expropriation across Subsets

\begin{tabular}{|c|c|c|c|c|c|c|c|c|}
\hline & \multicolumn{2}{|c|}{$\begin{array}{c}\text { XXVI) } \\
\text { All Countries }\end{array}$} & \multicolumn{2}{|c|}{$\begin{array}{c}\text { (XXVII) } \\
\text { Former Colonies }\end{array}$} & \multicolumn{2}{|c|}{$\begin{array}{c}\text { (XXVIII) } \\
\text { OECD }\end{array}$} & \multicolumn{2}{|c|}{$\begin{array}{c}\text { (IXXX) } \\
\text { Non-OECD }\end{array}$} \\
\hline & $\begin{array}{c}\text { Risk of } \\
\text { Expropriation }\end{array}$ & Y/L & $\begin{array}{c}\text { Risk of } \\
\text { Expropriation } \\
\end{array}$ & Y/L & $\begin{array}{c}\text { Risk of } \\
\text { Expropriation } \\
\end{array}$ & $\mathbf{Y} / \mathbf{L}$ & $\begin{array}{c}\text { Risk of } \\
\text { Expropriation } \\
\end{array}$ & Y/L \\
\hline $\begin{array}{l}\text { Risk of } \\
\text { Expropriation }\end{array}$ & & $\begin{array}{c}0.647 * * * \\
(0.064)\end{array}$ & & $\begin{array}{c}0.742 * * * \\
(0.120)\end{array}$ & & $\begin{array}{c}0.662 * * * \\
(0.100)\end{array}$ & & $\begin{array}{c}0.844 * * * \\
(0.227)\end{array}$ \\
\hline $\begin{array}{l}\text { Executive } \\
\text { Constraints }\end{array}$ & $\begin{array}{c}0.341 * * * \\
(0.079)\end{array}$ & & $\begin{array}{c}0.226 * * * \\
(0.119)\end{array}$ & & $\begin{array}{l}-0.059 \\
(0.210)\end{array}$ & & $\begin{array}{l}.521 * * \\
(.261)\end{array}$ & \\
\hline $\begin{array}{l}\text { Executive } \\
\text { Recruit. Reg. }\end{array}$ & $\begin{array}{l}0.485^{*} \\
(0.269)\end{array}$ & & $\begin{array}{c}0.394 \\
(0.383)\end{array}$ & & $\begin{array}{c}1.700 * * * \\
(0.604)\end{array}$ & & $\begin{array}{l}.075^{*} \\
(.0829)\end{array}$ & \\
\hline$\overline{\mathrm{N}}$ & 105 & 105 & 60 & 60 & 26 & 26 & 79 & 79 \\
\hline Adj. R-sq & 0.33 & 0.60 & 0.24 & 0.52 & 0.59 & 0.72 & 0.10 & -0.062 \\
\hline Over-ID Test & & 0.11 & & 0.75 & & 0.24 & & 0.219 \\
\hline
\end{tabular}

Notes: Not reported: Intercept; Robust standard errors in parentheses. Significance at the 10,5 and 1 percent levels are indicated by $* * *, * * *$, respectively. First stage always includes Constraints on the Executive (Executive Constraints) and Regulation of Chief Executive Recruitment (Executive Recruitment). The (instrumented) economic institutional variable now is Risk of Expropriation from McArthur and Sachs (2001) as is income per worker. Over-ID Test is the pvalue of the Hansen-Sargan Test statistic of overidentifying restrictions of all (but one) Instrument, the joint null being that the instruments are valid. The " "superscript indicates instrumented variables. 


\section{Appendix}

Table A1

Correlation Matrix of Political Institutions

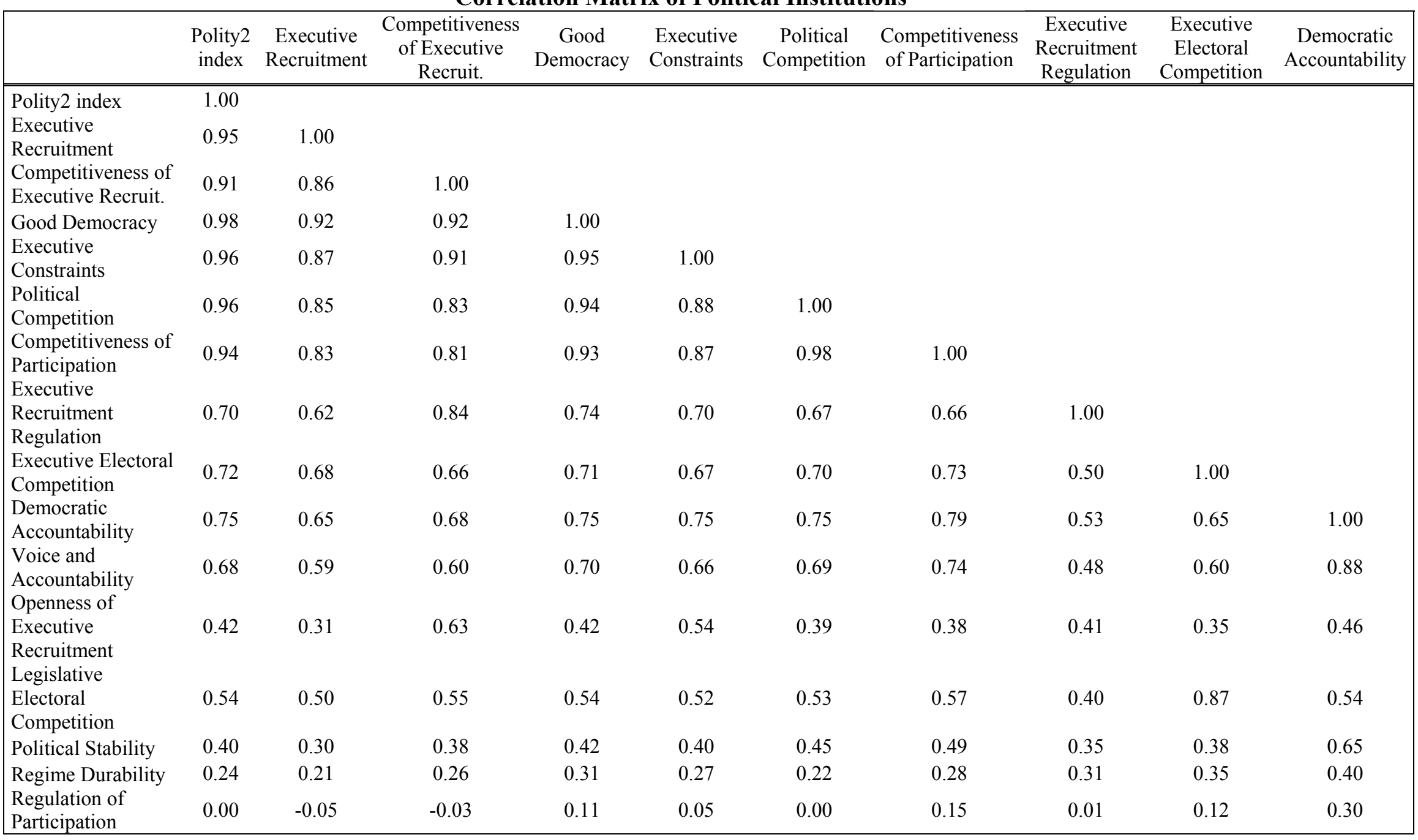


Table A1 (continued)

Correlation Matrix of Political Institutions

\begin{tabular}{|c|c|c|c|c|c|c|}
\hline & $\begin{array}{c}\text { Voice and } \\
\text { Accountability }\end{array}$ & $\begin{array}{l}\text { Openness of } \\
\text { Executive } \\
\text { Recruitment } \\
\end{array}$ & $\begin{array}{c}\text { Legislative } \\
\text { Electoral } \\
\text { Competition } \\
\end{array}$ & $\begin{array}{l}\text { Political } \\
\text { Stability }\end{array}$ & $\begin{array}{l}\text { Regime } \\
\text { Durability }\end{array}$ & $\begin{array}{l}\text { Regulation of } \\
\text { Participation }\end{array}$ \\
\hline $\begin{array}{l}\text { Voice and } \\
\text { Accountability }\end{array}$ & 1.00 & & & & & \\
\hline $\begin{array}{l}\text { Openness of } \\
\text { Executive } \\
\text { Recruitment }\end{array}$ & 0.33 & 1.00 & & & & \\
\hline $\begin{array}{l}\text { Legislative Electoral } \\
\text { Competition }\end{array}$ & 0.47 & 0.43 & 1.00 & & & \\
\hline Political Stability & 0.80 & 0.22 & 0.28 & 1.00 & & \\
\hline Regime Durability & 0.38 & 0.11 & 0.35 & 0.27 & 1.00 & \\
\hline $\begin{array}{l}\text { Regulation of } \\
\text { Participation }\end{array}$ & 0.34 & -0.05 & 0.16 & 0.33 & 0.45 & 1.00 \\
\hline
\end{tabular}

Notes: based on the 109 observations for which all data was available. 
Table A2

The Hierarchy of Institutions Factor Analysis

(Rotated Factor Loadings)

\begin{tabular}{|l|lccc|}
\hline & & \multicolumn{3}{c|}{ Factors } \\
\cline { 2 - 5 } Economic Institutions & & $\mathbf{1}$ & $\mathbf{2}$ & $\mathbf{3}$ \\
\hline & Rule of Law & 0.35 & 0.88 & 0.14 \\
& Government effectiveness & 0.35 & 0.87 & 0.14 \\
& Corruption & 0.32 & 0.87 & 0.17 \\
& Government Anti-Diversion Policies & 0.32 & 0.85 & 0.27 \\
& Social Infrastructure & 0.41 & 0.85 & -0.02 \\
& Regulatory Quality & 0.37 & 0.79 & 0.01 \\
& Years Open & 0.42 & 0.74 & -0.18 \\
\hline \multirow{5}{*}{ Political Institutions } & Polity2 index & 0.93 & 0.32 & 0.08 \\
& Executive Recruitment & 0.90 & 0.24 & 0.02 \\
& Competitiveness of Executive Recruit. & 0.90 & 0.24 & 0.24 \\
& Good Democracy & 0.89 & 0.37 & 0.13 \\
& Executive Constraints & 0.88 & 0.29 & 0.21 \\
& Political Competition & 0.88 & 0.38 & 0.04 \\
& Competitiveness of Participation & 0.81 & 0.47 & 0.12 \\
& Executive Recruitment Regulation & 0.77 & 0.25 & 0.15 \\
& Executive Electoral Competition & 0.58 & 0.33 & 0.53 \\
& Democratic Accountability & 0.52 & 0.66 & 0.30 \\
& Voice and Accountability & 0.44 & 0.77 & 0.17 \\
& Openness of Executive Recruitment & 0.43 & 0.01 & 0.56 \\
& Legislative Electoral Competition & 0.42 & 0.26 & 0.67 \\
& Political Stability & 0.19 & 0.81 & 0.06 \\
& Regime Durability & 0.09 & 0.49 & 0.36 \\
& Regulation of Participation & -0.26 & 0.55 & 0.31 \\
\hline
\end{tabular}

Note: based on 103 observations for which all data was available. 
Table A3

Factor Analysis of Political Institutions

(Global Sample, Rotated Factor Loadings)

\begin{tabular}{|lcc|}
\hline & \multicolumn{2}{c|}{ Factors } \\
\cline { 2 - 3 } & $\begin{array}{c}\text { "Democratic } \\
\text { Rules" }\end{array}$ & $\begin{array}{c}\text { "Participation and } \\
\text { Stability" }\end{array}$ \\
\hline Polity2 index & 0.94 & -0.04 \\
Good Democracy & 0.93 & 0.11 \\
Executive Recruit. Competitiveness & 0.91 & -0.07 \\
Political Competition & 0.88 & -0.08 \\
Executive Constraints & 0.87 & 0.04 \\
Competitiveness of Exec. Recruit. & 0.86 & 0.06 \\
Competitiveness of Participation & 0.84 & 0.05 \\
Executive Recruitment Regulation & 0.76 & 0.27 \\
Democratic Accountability & 0.56 & 0.19 \\
Executive Electoral Competition & 0.55 & 0.08 \\
Voice and Accountability & 0.49 & 0.19 \\
Legislative Electoral Competition & 0.35 & 0.13 \\
Openness of Executive Recruitment & 0.25 & -0.08 \\
Political Stability & 0.24 & 0.20 \\
Regime Durability & 0.18 & 0.52 \\
Regulation of Participation & -0.09 & 0.79 \\
\hline
\end{tabular}

Note: based on 109 observations for which all data was available. 